\title{
AM/SLM 技術による金属積層造形の動向と開発状況
}

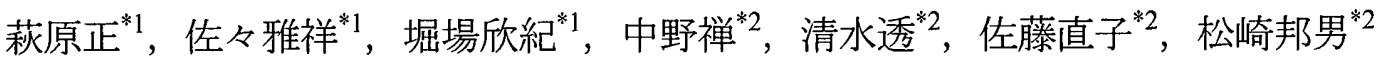

\section{Trend and Development Status of Metal Additive Manufacturing}

\author{
Masashi HAGIWARA $^{* 1}$, Masahiro SASSA ${ }^{* 1}$, Yoshinori HORIBA ${ }^{* 1}$, \\ Shizuka NAKANO ${ }^{* 2}$, Toru SHIMIZU ${ }^{* 2}$, Naoko SATO $^{* 2}$, and Kunio MATSUZAKI ${ }^{* 2}$ \\ ${ }^{{ }^{*} 1}$ Aspect Inc \\ 3104-1-101, Higashi-Naganuma, Inagi, Tokyo, 206-0802 Japan \\ ${ }^{* 2}$ National Institute of Advanced Industrial Science and Technology \\ Low-Formability-Materials Processing Group \\ Advanced Manufacturing Research Institute \\ AIST Tsukuba East, 1-2-1, Namiki Tsukuba, Ibaraki, 305-8564 Japan
}

Metal Additive Manufacturing Technology is coming into practical use gradually. We, as a member of ALPROT, which stands for Advanced Laser and Process Technology Research Association, developed a new Selective Laser Melting platform with a high-vacuum process chamber in collaboration with AIST (National Institute of Advanced Industrial Science and Technology). In this report, the trend of Metal Additive Manufacturing in the world and the development status of the Selective Laser Melting platform are mainly introduced.

Key Words : Metal Additive Manufacturing, Selective Laser Melting, Fiber Laser, Vacuum Chamber

\section{1. 緒言}

3D のデジタルデータから直接金属粉末にレーザーを選択的に照射し溶融することで最終製品を造形可能な金 属積層造形（Metal Additive Manufacturing）は近年実用化が進みつつある．筆者らは 2010 年から開始した，独立 行政法人新エネルギー・産業技術総合開発機構（NEDO）の委託事業「次世代素材等レーザー加工技術開発プロ ジェクト」において，技術研究組合次世代レーザー加工技術研究所（略称 ALPROT）の組合員として，産業技術 総合研究所（AIST）とともに，造形環境を真空にした金属粉末積層造形装置の研究開発を進めている。

本稿では，研究開発を進めるにあたり調査した金属粉末積層造形に関する世界の技術動向と現在研究開発中の 真空型金属粉末積層造形装置について紹介をする.

\section{2. 金属粉末積層造形に関する世界の技術動向}

\section{$2 \cdot 1$ 市販の装置}

金属粉末を直接溶融しながら部品を造形する技術には大きく分けて 2 つの方式があり,以下に簡単に紹介する.

\section{2・1・1 LMD（Laser Metal Deposition）方式}

図 1 に Laser Metal Deposition 原理図を示す。本方式は LENS (Laser Engineered Net Shaping) や DMD (Direct Metal

\footnotetext{
${ }^{{ }^{*} 1}$ 株式会社 アスペクト hagiwara@aspect-rp.co.jp （テ206-0802 東京都稲城市東長沼 3104-1-101）

*2 独立行政法人 産業技術総合研究所 先進製造プロセス研究部門 難加工材成形研究グループ (テ305-8564 茨城県つくば市並木 1-2-1 つくば東)
} 
Deposition）とも呼ばれている方式で，レーザーが照射されている部位に対して金属粉末を噴射して溶融・固化し て造形をしており, Optomec 社から商用装置が販売されている. 旧 POM Group も同方式の装置を開発販売してい たが, DM3D Technology 社に買収され, 現時点では受託サービスのみで装置は販売していない. 次項で述べる SLM 方式に比較して，既存部品の修理に向いていることや多種材料を使用することができる利点はあるが，加工速度 が遅いことや不活性もしくは真空雰囲気にするためには装置が大がかりになってしまう課題がある.

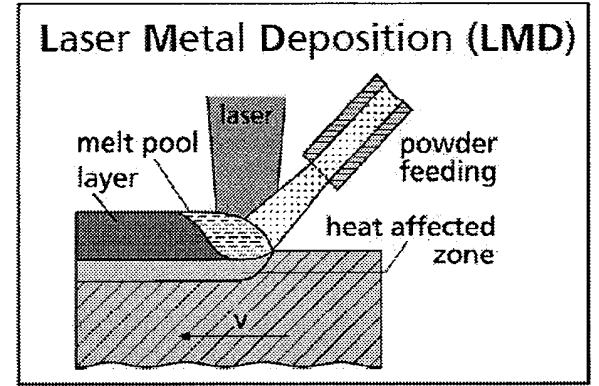

図 1. Laser Metal Deposition 原理図

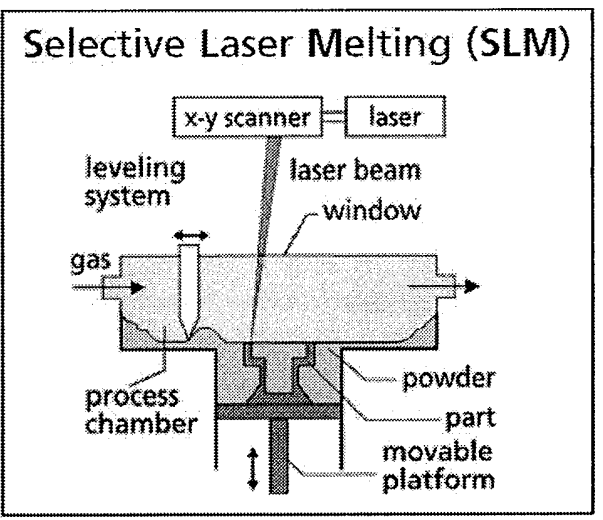

図 2. Selective Laser Melting 原理図

\section{$2 \cdot 1 \cdot 2$ SLM（Selective Laser Melting）方式}

図 2 に Selective Laser Melting 原理図を示す．金属粉末を積層しながら直接レーザーもしくは電子ビームのよう なエネルギー源により造形する方式で，主にヨーロッパで研究開発が進められてきた，そのため，現在販売され ている装置のほとんどは全てヨーロッパの製品である. 3D Systems も販売しているが, Renishaw 社の OEM 供給 を受けている．以下に SLM 方式の装置を簡単に紹介する. 紙面の関係で全ての装置の写真掲載は割愛する.

(1) $\operatorname{EOS(ドイツ)~}$

EOS 社は最も古くから直接焼結による造形装置を手がけてきた会社で，この技術のことを DMLS（Direct Metal Laser Sintering）と呼んでいる. M280 は250×250×325mm の造形サイズの最新の装置で，200W また は 400W のファイバーレーザーを搭載している。昨年冬に発表された新機種 M080 は，金，プラチナ，パ ラジウム，銀などの貴金属粉末用の造形装置で，造形サイズとして直径 $80 \times 100 \mathrm{~mm}$ を有している.

(2) Concept Laser（ドイツ）

昨年の Euromold で展示された X line 1000R は, $630 \times 400 \times 500 \mathrm{~mm}$ の造形サイズを有する巨大な装置 で, $1 \mathrm{~kW}$ のファイバーレーザーを搭載し，アルミ合 金の直接造形が可能とされている. (図 3 参照)この 装置は Fraunhofer と Daimler との共同研究で開発さ れ, 既に Daimler で稼働中である. 装置手前に配置 されている台は展示用の台ではなく, 装置に標準で 装備されている台である.

他に金属造形のラインナップとして, M1 Cusing（造 形サイズ : $250 \times 250 \times 250 \mathrm{~mm}$ )，M2 Cusing（同 :

$250 \times 250 \times 280 \mathrm{~mm}$ ), MLab Cusing (同 : $90 \times 90 \times 80 \mathrm{~mm}$ ) の 3 機種がある。なお、2013 年 5 月に Concept Laser

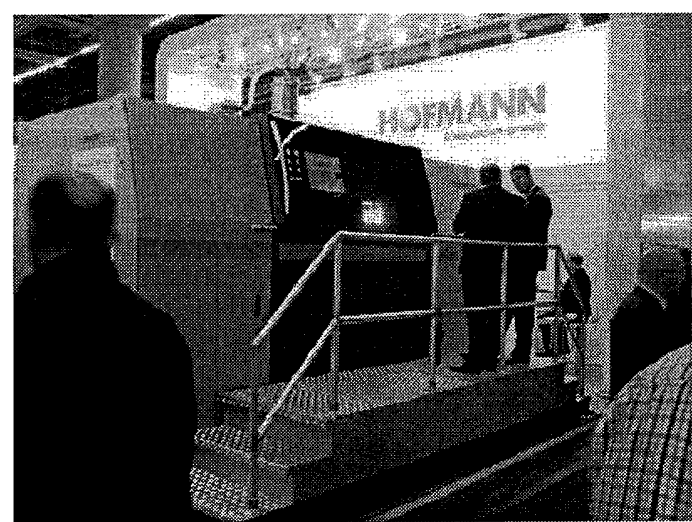

図 3. X line 1000R 社と EOS 社はクロスライセンスと係争中の全ての特許訴訟を取り下げる事に関し合意した.

(3) SLM Solutions（ドイツ)

SLM Solutions 社は，英MTT 社が Renishaw 社に買収された際に切り離されたドイツの部門で, SLM125HL

(造形サイズ : $125 \times 125 \times 75 \mathrm{~mm}$ ), SLM250HL(同 : $250 \times 250 \times 350 \mathrm{~mm}$ ), SLM280HL（同 : $280 \times 280 \times 350 \mathrm{~mm}$ ), SLM500HL (同 500×280×325mm) の 4 サイズのプラットフォームを製品化している. それぞれ $100 \mathrm{~W} / 200 \mathrm{~W}$ ， 
200W/400W，400W/1000W，2×400W/1000W という構成で, 全て Low/High 2 台の CW ファイバーレーザー を搭載しており，ダブルビームテクノロジーと呼んでいる. 造形する部品の外郭は, 低速度, Low Power, ガウシアンビームで走査し，内部構造の塗りつぶしは，高速度，High Power，ハットトップビームでレー ザーを切り替えて走查をすることで高速性を高めるという特徴を有している.

(4) Realizer (ドイツ)

Realizer 社は，創業者 2 人の名字にちなんで F\&S という社名であったが、1999年に Fraunhofer ILT と共同 で研究開発を進めてスチールベースの SLM 装置を開発したのが始まりである．現在は SLM50（造形サイ

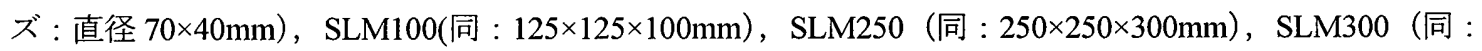
$300 \times 300 \times 300 \mathrm{~mm})$ の 4 サイズのプラットフォームを製品化している.

(5) Renishaw (イギリス)

Renishaw 社は接触型の計測用プローブで有名だが, 2011 年に MTT Technology 社を買収して, 金属造形の 業界に参入した. 買収される前の MTT 社は Realizer 社の装置の販売代理店として活動していたが，真空注 型装置を手がけていたことからか，造形前の不活性ガスを注入する前にチャンバ内を真空にすることによ り,酸素濃度を極力低くする特長を有している. 現在は AM125 (造形サイズ: $125 \times 125 \times 125 \mathrm{~mm}$ ), と AM250

(同： $250 \times 250 \times 300 \mathrm{~mm})$ を製品化しており，同装置は3D Systems 社に OEM供給されている.

(6) Phenix Systems (フランス)

PXS, PXM, PXL の 3 機種に PXS Dental, PXM Dental の 2 機種を製品化している. 製品名称の末尾の S/M/L

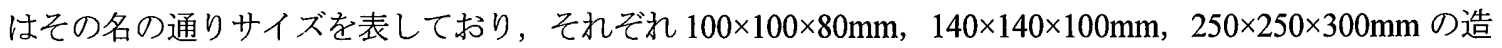
形サイズとなっている.

昨年 3 月に EOS 社に米国内での特許抵触の訴訟を起されたことに対抗して, 7 月に EOS を提訴した. 未だ いずれの結論も出ていないが，3D Systems 社が本年 6 月にPhenix Systems の 80\%を買収したとの情報が報 道されている.

(7) Arcam (スウェーデン)

世界で唯一電子ビームにより造形する装置を製品化しており，現在は造形サイズ $100 \times 100 \times 80 \mathrm{~mm}$ の Q10(従 来機種 A1 の後継機種）と A2 の 2 機種がある. A2 については造形サイズ 200×200×350mm が標準である が，オプションで $200 \times 200 \times 380 \mathrm{~mm}$ ，直径 350×380を選択することも可能である. エネルギー源として電子 ビームをしていることから，造形環境を真空にすることが必須であり，チタン合金のような酸化し易い金 属の造形に適している.

（8）松浦機械製作所

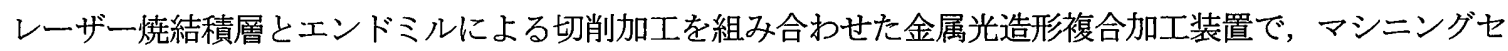
ンタでの加工と同レベルの精度を実現することが可能で，特に金型の試作に向いている装置である.

\section{$2 \cdot 2$ シンポジウムでの情報}

Additive Manufacturing に関する国際会議は，今年で 24 回目を数えるテキサス大学の SFFS（Solid Freeform Fabrication Symposium), 会議名は 2 回変更になっているが通算で 8 回目になる Nottingham 大学の Additive Manufacturing \& 3D Printing International Conference（2011 年までは Loughborough 大学で開催されており，AMC (Additive Manufacturing International Conference), 2008 年まではRMC (Rapid Manufacturing International Conference), Fraunhofer 主催の DDMC (Direct Digital Manufacturing Conference), EuroMold に併設の International Wohlers Conference などがあるが、最近は3D プリンターブームでもっと増えているようである．筆者が参加した中で 最近気になった情報をいくつか列挙する. 紙面の関係で詳細は割愛する.

\section{2 2 - 1 AMC2011}

(1) GEの取り組み GEの発表において,「エンジンの少なくとも50\%はAM 技術を利用して作られるだろう」と発言しており， 着々と生産へ準備中である.

(2) Direct Spare 
スペアパーツを必要な場所で必要なときに AM 技術を利用して製作するためにヨーロッパの企業 15 社が 国を超えて規格や仕組みを作ることで，在庫部品やそれを保管するための倉庫，製造原価が安価な生産場 所から保管場所および保管場所から使用場所への輸送, 設計変更や生産中止により必要なくなった部品の 廃棄等，従来は必要だった無駄をなくし，製造を原価が安価な地域からヨーロッパに戻そうとするプロジ エクトが現在進行形である.

\section{$2 \cdot 2 \cdot 2$ 14th Annual International Wohlers Conference（EuroMold2012)}

(1) 南アフリカ Aerosud 社の取り組み

Aerosud 社は売上の 95\%以上を輸出しているプライベートカンパニーで主要顧客はエアバスとボーイング. 国立レーザーセンターとのコラボレーションで 2020 年までに完了予定の研究開発を実施している. 装置の 開発仕様は, レーザー出力 : $5 \mathrm{KW}$, 造形サイズ : $2000 \times 620 \times 620$, 走查速度 : $50 \mathrm{~m} / \mathrm{s}$ という巨大な造形サ イズで高速な加工速度を目指してプロジェクトが進行中.

(2) NAMII (National Additive Manufacturing Innovation Institute) 既に日本でもテレビで報道されているが，オバマ大統領の一般教書演説でも宣言された国立の AM 研究機 関に関する報告. DOD (Department of Defence : 国防 総省）が多額の予算を負担して,アメリカが総力を 挙げて AM 技術の研究開発に取り組みを開始した.

(3) Jewellery Industry Innovation Centre Birmingham City University School of Jewellery (UK)

貴金属粉末を直接焼結して少量多品種の宝飾品を生 産する研究が進んでいる. 例えば図 4 に示すように 高級品を取り扱っていることで有名な百貨店ハロッ ズでは, 27,500 ポンドという価格で複雑な形状の $18 \mathrm{~K}$ ゴールドフレームの万年筆が販売されている.

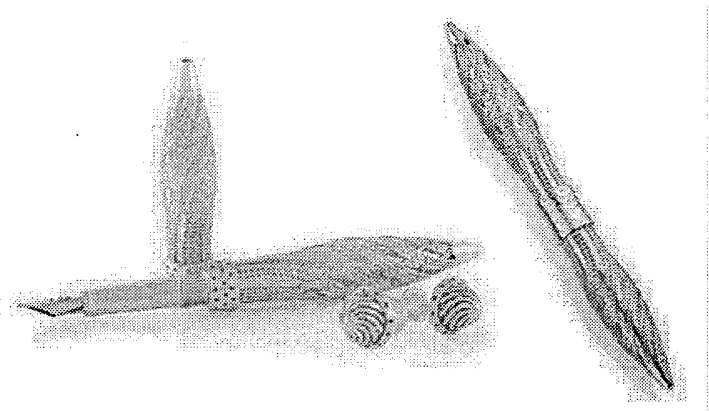

図 4. ハロッズで販売されている万年筆

\section{3. 真空型金属粉末積層造形装置の開発}

NEDO の委託事業「次世代素材等レーザ一加工技術開発プロジェクト」において，技術研究組合次世代レーザ 一加工技術研究所（略称ALPROT）の組合員として，産業技術総合研究所（AIST）と共同で開発した装置は，基 礎実験をするための小型プラットフォーム（造形テーブルサイズ $150 \times 150 \mathrm{~mm}$ ，造形深さ $200 \mathrm{~mm}$ ） と，実用サイ ズプラットフォーム（造形テーブルサイズ $300 \times 300 \mathrm{~mm}$, 造形深さ $400 \mathrm{~mm}$ ）の 2 機種であり，同じく ALPROT の 組合員である古河電工（株）が新規に開発した基本波 $700 \mathrm{~W}$ QCW（Quasi Continuous Wave）ファイバーレーザー を搭載した. 図 5 に小型プラットフォーム, 図 6 に実用サイズプラットフォームの写真を示す. 開発装置では波 長 $1 \mu \mathrm{m}$ 帯のレーザー光が国産デジタルガルバノスキャナにより、スライスデータから作成された描画パターンに 沿ってスキャンする方法を用いている，レーザー光は石英ガラスを通して装置内人導入している.

最大の特長は金属の酸化を防ぐために造形環境を高真空とし，400L/sec の排気量を持つターボ分子ポンプ (TMP) および背圧用にロータリーポンプ（RP）を搭載していることである．RPによる粗引きと TMP による本 引きにより概初 15 分で成形真空度 $1.0 \times 10^{-2} \mathrm{~Pa}$ 以下を達成している. この真空度では分子の平均自由行程はおよ そ $70 \mathrm{~cm}$ 以上でありチャンバーサイズと同等となる. 現在は 1.0×10-3 Pa 以下の到達真空度が得られている.

また，実用型プラットフォームはチャンバーサイズが大きいことから，685L/sec の排気量を持つターボ分子ポ ンプを搭載している. 


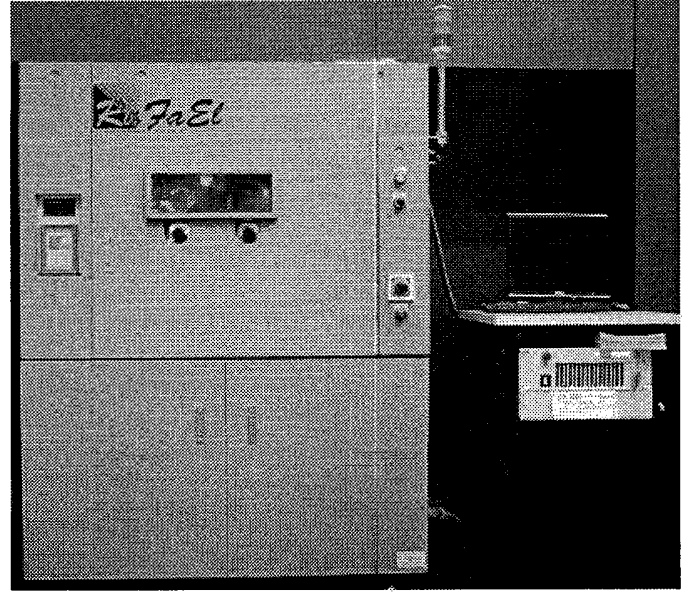

図 5. 小型プラットフォーム試作機

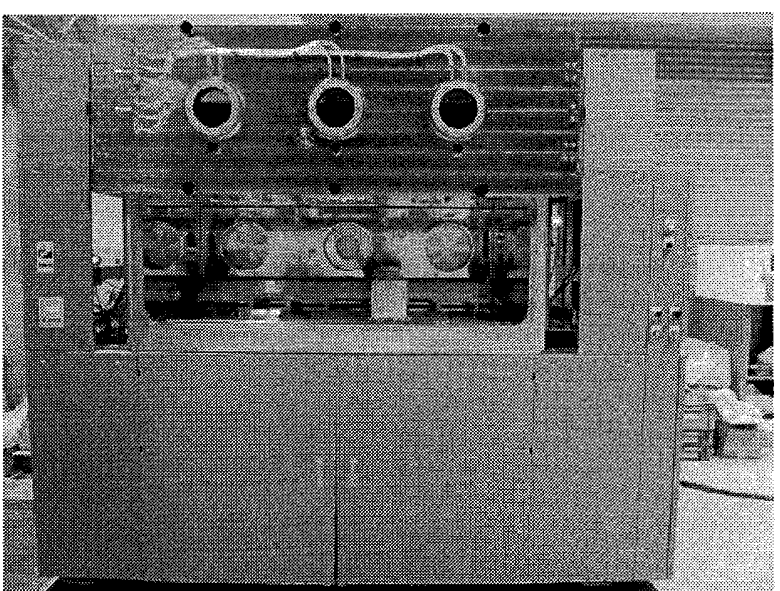

図 6. 実用サイズプラットフォーム試作機

\section{4 真空型金属粉末積層造形装置での造形実験}

開発した小型プラットフォームを用いて造形実験を行った。利用した粉末は大阪チタニウムテクノロジー社製

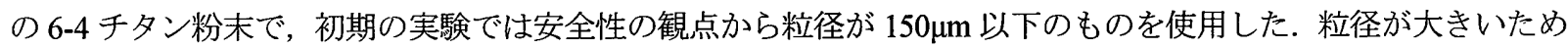
当初の積層厚さは $0.2 \mathrm{~mm}$ とした. レーザーパワーなど造形条件を変更しながら密度評価実験用試験片として, $10 \mathrm{~mm} \times 8 \mathrm{~mm} \times 1 \mathrm{~mm}$ 程度の直方体の成形試験を行った. 図 7 に密度評価実験用試験片と断面写真を示す。粒径が $150 \mu \mathrm{m}$ 以下の材料を使用した際の各層の厚さは $200 \mu \mathrm{m}$ であり, 層状の構造かつ各表面層は十分に溶融しているも のの，内部の粒子が残っている（結合はしている）状態がはっきり見られる.これは特にレーザーパワーが低い と顕著であり，これに併せたように密度は 2.4〜3.1 g/cm3 となっていて，6-4 チタンの標準を $4.37 \mathrm{~g} / \mathrm{cm} 3$ とすると 55〜71\%程度の相対密度であることがわかる. 次に, 密度を向上させる目的で, $150 \mu \mathrm{m}$ からふるいで抽出した $75 \mu \mathrm{m}$ 以下の材料を使用して造形実験を行なった．粒径が小さくなったことにより，これまでの $200 \mu \mathrm{m}$ の積層厚さを $150 \mu \mathrm{m} \sim 120 \mu \mathrm{m}$ まで薄くすることができた．また， $75 \mu \mathrm{m}$ 以下の材料による造形物は，密度も $2.9 \sim 3.6 \mathrm{~g} / \mathrm{cm} 3$ で相 対密度が 66〜82\%へと向上した. さらに $45 \mu \mathrm{m}$ 以下の材料を使用することにより，積層厚さは $100 \mu \mathrm{m}$ まで薄くで き, 密度は、3.5 4.0 g/cm3 で 80 91\%まで向上した. 使用した材料の粒径と密度の関係を表 1, $45 \mu \mathrm{m}$ 以下の材 料で造形した造形物の写真を図 8 に示す. 粒径が $150 \mu \mathrm{m}$ 以下の材料を使用したときには焼結としては不十分だっ たものが，粒径を小さくすることと造形条件の変更により著しく密度が改善された. 今後さらに適切な焼結状態 を得るために，その造形条件を見出す事が不可欠である.
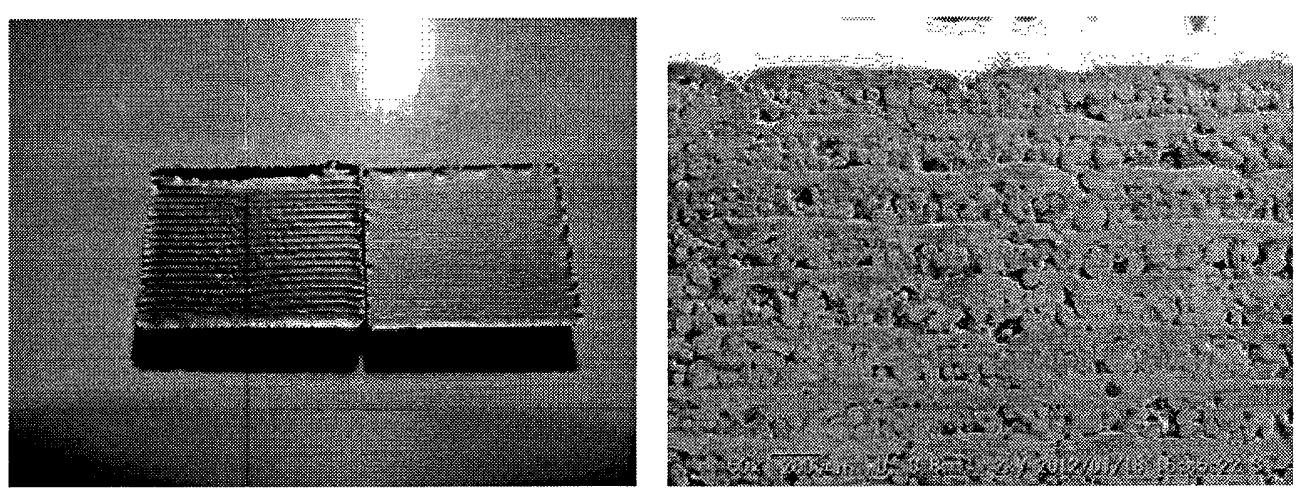

図 7. 密度評価実験用試験片と断面写真 
表 1．材料の粒径と密度の関係

\begin{tabular}{|c|c|c|c|}
\hline Particle Size $(\mu \mathrm{m})$ & Layer Thickness $(\mu \mathrm{m})$ & Laser Power $(\mathrm{W})$ & Density $\left(\mathrm{g} / \mathrm{cm}^{3}\right)$ \\
\hline 150 & 200 & 150 & 3.1 \\
\hline 75 & 120 & 100 & 3.6 \\
\hline 45 & 100 & 100 & 4.0 \\
\hline
\end{tabular}
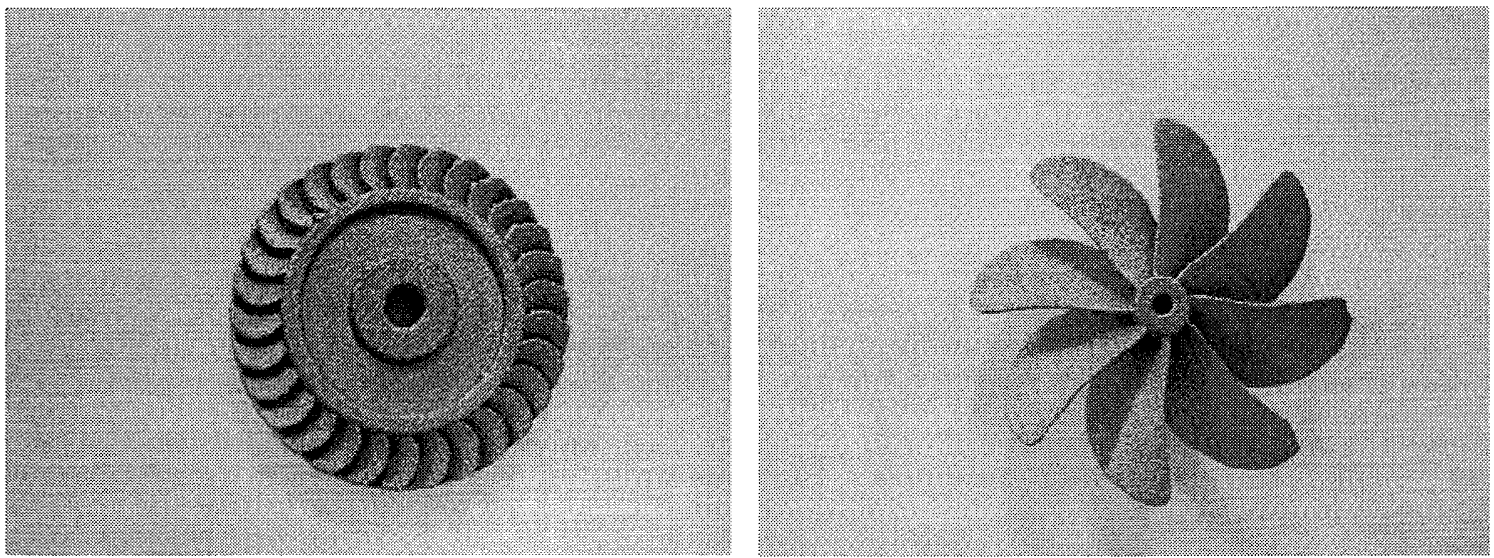

図 8. $45 \mu \mathrm{m}$ 以下の材料で造形した造形物

\section{5. まとめ}

QCW ファイバーレーザーを用いた真空型金属粉末積層造形装置を開発し，6-4 チタン合金粉末を使用した造形 試験を行なった．その結果，任意の立体形状が造形可能である事を示すことができた.

また，材料の粒径や造形条件の最適化により，ある程度の密度が得られることも示した．今後，用途に合わせ た密度の調整や成形物の精度向上など，さらなる造形条件の最適化を図っていきたい.

\section{6. 謝辞}

本研究の一部は NEDO プロジェクト「次世代素材等レーザー加工技術開発プロジェクト」の委託により行わ れました。感謝の意を表します。

\section{文献}

（1）京極秀樹，“レーザー積層造形技術の動向と実際”，第 78 回レーザ加工学会講演論文集（2012.12）,pp.71-75

(2) 株式会社アスペクト・ALPROT 萩原正、O佐々雅祥、堀場欣紀、産業技術総合研究所・ALPROT 中野禅、清 水透、松崎邦男 “ファイバーレーザーを用いた金属粉末成形技術の開発”，溶接学会 平成 25 年度春季全国大会 シンポジウム

(3) Ingomar Kelbassa, "High-speed Laser Additive Manufacturing LAM", 14 ${ }^{\text {th }}$ Annual International Wohlers Conference, Euromold2012

(4) Frank Cooper, "The Commercial State of the Art in Precious Metal Sintering", 14 ${ }^{\text {th }}$ Annual International Wohlers Conference, Euromold2012 